1921 and 1949-50, and the results were published in a series of six volumes between 1914 and 1953 .

In 1934, he was elected Brunner professor of Egypt. ology in the University of Liverpool, and held this post until his retirement in 1948. Academic and other responsibilities limited his opportunities of visiting Egypt; but 1936-37 saw him once again in the Sudan as director of the Egypt Exploration Society's excavations at Sesebi.

Blackman's main scientific interest was in the religion of Ancient Egypt, particularly its liturgy and ritual. Unfortunately, he never wrote a book on the subject that was nearest to his heart; but his most important contributions to Egyptology certainly lie in the numerous papers which he contributed to the leading Egyptological journals. Typical of these are his massive contributions on such subjects as "Priesthood", "Purification" and "Worship" to Hastings's "Encyclopædia of Religion and Ethics" which still retain all their freshness and value.

$\mathrm{He}$ was a magnificent teacher. $\mathrm{He}$ liked young people, and his deep knowledge of his subject, coupled with a lively and warm sympathy with and understanding of his students, made him an inspiring teacher. Above all, he was interested in showing that Ancient Egypt was alive: to him there were no dead bones in archæology, and this was reflected not only in his scientific papers, but also in his popular writings, such as his delightful "Luxor and its Temples" (1923), which was also translated into German, his "Literature of the Ancient Egyptians" (1927), a translation of Erman's original work and still the only book of its kind in English, and in his inaugural lecture, "The Value of Egyptology in the Modern World" (1936). Of all British Egyptologists, he was possessed of a real sense of style and language: his translations, even if they had perhaps rather too strong a Biblical flavour, were vivid, accurate and attractive, and his commentaries displayed that same gift of expression allied to deep learning.

Blackman's last years were clouded with tragedy and misfortune. When returning from Meir in 1950 he broke his hip on board ship, and returned home on a stretcher, only to discover that his home had been broken up by the tragic fate of his sisters. Throughout his life he had been peculiarly devoted to his family: this double blow was one from which he never really recovered, and his years of retirement were marked by increasing physical weakness and pain. His election in 1952 as a Fellow of the British Academy was a recognition of his contributions to Egyptology that brought him great cheer in his last difficult years. A great scholar, an inspiring teacher, a very human and kindly man, deeply religious, and in private life the most unselfish and sincere of friends, his death removes one of very great gifts whose place, in his own special field, it will be hard to fill.

$$
\text { H. W. Fatrman }
$$

\section{Prof. Samson Wright}

THE sudden death on March 11 of Prof. Samson Wright came as a great shock to his many friends; he was fifty-six years of age.

Samson Wright ('Sammy' to his colleagues) entered the Middlesex Hospital Medical School as a student in 1916 and, apart from one year when he was lecturer in physiology at King's College in 1929, he remained at the Middlesex until his death. After gaining the Gold Medal in the M.B., B.S. examination in 1922, he became senior demonstrator in the Department of Physiology under the late Prof. Swale Vincent, and, after his brief sojourn at King's College, he was appointed as the first John Astor professor of physiology at the Middlesex Hospital Medical School when Prof. Swale Vincent retired in 1930. In 1931 ho gave the Oliver-Sharpey Lecture at the Royal College of Physicians on "Certain Aspects of the Reflex Control of the Circulation" and in 1933 he was elected a Fellow of the College.

Wright's services to physiology were many; but there is no doubt that his greatest contribution was as a teacher. Both as a lecturer and as the author of the well-known "Applied Physiology" (first published in 1926 and now in its ninth edition) he was supreme. His vast knowledge, his critical insight and his fluent exposition could make the most difficult topic seem simple, and he had a wonderful gift for stimulating others to think for themselves. $\mathrm{He}$ believed that physiology was the corner-stone of medicine, and his classic text-book is a vivid commentary on this theme.

During 1938-4.9 Wright served the Physiological Society as editor of Physiological Abstracts, and during this difficult time he developed it into an indispensable scientific publication.

Samson Wright made notable original contributions to the physiology of the circulation, respiration and the central nervous system. In his early work on the circulation, he was the first to show that ergotamine abolishes the response of the vasomotor centre to sino-aortic afferent impulses. His most important work on respiration was the demonstration with Selladurai that anoxic hyperpnoea is entirely dependent on chemoreceptors, whereas carbon dioxide hyperpnoa is unaffected by sino-aortic nerve section. He also studied the action of acetylcholine and related compounds on chemoreceptors and put forward the hypothesis that acetylcholine might be the transmitter substance in the glomus.

Wright worked with various colleagues for many years on the complex problem of chemical transmission within the central nervous system, and studied the actions of anticholinesterases such as eserine, neostigmine and diisopropylfluorophosphonate. They suggested that the differences between the central actions of the first two drugs were due to the fact that eserine is a tertiary compound which penetrates cell membranes easily, whereas neostigmine is a quaternary compound which does not.

Recently he had been investigating the effects of injection of $d$-tubocurarine into various parts of the brain as revealed by electrical wave patterns recorded from different areas.

Apart from his own work, Wright was a most inspiring and enthusiastic director of research, though he was very eritical of anything which fell below his own high standards.

Wright had many interests outside physiology. $\mathrm{He}$ was an enthusiastic Zionist and he did all that was humanly possible to help those Jewish refugees who came to Britain from Hitler's Germany. After the establishment of the State of Israel, he took a great interest in the Hebrew University of Jerusalem, of which he was a governor. He was also vice-chairman in Britain of the Friends of the Hebrew University. He helped to build up the University's Faculty of Medicine along traditional British lines, and it is most fitting that a laboratory in its Department of Physiology was recently named after him. 
In Samson Wright great intellectual brilliance was linked with a most lovable character. He was a formidable but always constructive critic, and he took a constant, unselfish interest in the welfare of his colleagues and staff. His great gift of exposition, combined with humility and sincerity of purpose, made him a most stimulating and delightful companion. His challenging personality will be greatly missed. His wife died in 1950 and he leaves three daughters.
C. A. Keele

\section{NEWS and VIEWS}

\section{Mellon Institute of Industrial Research, Pittsburgh :} Dr. E. R. Weidlein

Dr. Edward R. WeIdLeIN retired on March 31 from the presidency of the Mellon Institute of Industrial Research, Pittsburgh, after more than forty years of active work at the Institute. Happily, his retirement will not sever his connexion with the Institute as he will remain on the Board of Trustees and will be available in an advisory capacity in the administration of the various research programmes. His successor as head of the research executive staff of the Institute has not yot been announced. Dr. Weidlein joined the Mellon Institute in 1912, becoming acting director during the First, World War and then director in 1921. In 1951 he was appointed president of the Institute and, in addition, he was for four years chairman of the Board of Trustees, a post which he relinquished last year. The Mellon Institute, which is associated with the University of Pittsburgh, is an endowed, nonprofit organization, conducting long-term investigations in chemical and physical technology, mainly by a system of industrial fellowships, and it is with this industrial fellowship scheme that Dr. Weidlein has been particularly concerned. However, he has also had many activities outside the Institute, and mention must be made of his work during the Second World War, as head technical consultant in the War Production Board, when he was largely instrumental in establishing the synthetic rubber industry in the United States. In Pittsburgh he is deeply interested in the health, well-being and community development of his home city and its surroundings and, in particular, in the control of industrial pollution. In 1938 the American Section of the Society of Chemical Industry awarded Dr. Weidlein the Chemical Industry Medal, and in 1948 he received the Priestley Medal of the American Chemical Society. He was president of the American Institute of Chemical Engineers during 1927-29.

\section{Imperial College of Science and Technology: Honorary Fellowships}

HoNORARy fellowship of the Imperial College of Science and Technology has been conferred on the following, all of whom have been connected with the College in various ways : Prof. William Brown, formerly professor of plant pathology ; Prof. Sydney Chapman, formerly professor of mathematics; Mr. David Garnett, author, and a former student; Dr. Willis Jackson, formerly professor of electrical engineoring; Prof. J. W. Munro, formerly professor of zoology and applied entomology; Sir William Penney, director of the Atomic Weapons Research Establishment, a member of the Governing Body and a former student; and Dr. W. F. G. Swann, director of the Bartol Research Foundation of the Franklin Institute, U.S.A., and a former student.

\section{Industrial Fund for the Advancement of Scientific Education in Schools}

IT was announced last November that seventeen firms had agreed to form an Industrial Fund to assist in the teaching of science in independent and direct-grant schools in Great Britain by the provision of capital grants towards the building, expansion, modernizing and equipping of science laboratiories (see Nature, November 5, p. 860). It was originally intended to raise $£ 1,500,000$; but seventy-three more companies have since agreed to support tho Fund, and the total now subscribed from all sources is $£ 2,900,000$. The committee for administering the Fund has appointed the following four assessors to act as technical advisers both to the committee and to the schools concerned: Sir Graham Savage, formerly sonior chief inspector of the Ministry of Education and thereafter chief education officer of the London County Council; Mr. D. B. Briggs, formerly one of H.M. inspectors of schools; Mr. W. F. Bushell, formerly headmaster of Birkenhead School ; and Mr. A. G. McKimmie, formerly headmaster of Allan Glen's School, Glasgow, whose special province is schools in Scotland and Northern Ireland.

An architectural brochure of current good practice for the building and equipping of school science laboratories has been prepared, which includes a table of standards of space and cost judged appropriate for the various types of buildings and equipment. It has been decided that, in the main, grants will be restricted to the teaching of the fundamental sciences of physics, chemistry and mathematics, that grants will not exceed two-thirds of the cost of that part of the project which is admissible for consideration, and that priority will be given to schools having 250 or more pupils over the age of thirteen and having at least 10 per cent of them in the mathematics and science sixth forms (the forms after the Ordinary Level of the General Certificate of Education). 439 schools have applied for grants from the Fund, and some interesting statistics have been compiled from their applications. In boys' schools the proportion in the mathematics and science sixth forms is now 50 per cent of the total in sixth forms, and while the total number of pupils over the age of thirteen has increased by more than a third since before the Second World War, there are now two and a quarter times as many boys specializing in mathematics and science. As a result, the facilities for teaching science are overcrowded and inadequate. Unlike maintained schools in Britain, the chief problem for independent and direct-grant schools is not a lack of science teaching staff but one of money for capital projects, and it is for this that the Fund has been created. On the basis of the applications, it has been decided to try to raise a further $£ 600,000$ to bring the Fund to a total of $£ 3,500,000$, and an appeal will be made shortly for this extra money. 